\title{
Urgensi Plea Bargaining System Dalam Pembaruan Sistem Peradilan Pidana Di Indonesia: Studi Perbandingan Plea Bargaining System Di Amerika Serikat
}

\author{
Ruchoyah \\ Magister Ilmu Hukum Universitas Brawijaya Malang \\ Jln. Hangtuah No. 28 Kota Pasuruan \\ ruchoyah@gmail.com
}

Received: 1 Mei 2020; Accepted: 1 Juli 2020; Published: 25 Agustus 2020

DOI: 10.20885/iustum.vol27.iss2.art9

\begin{abstract}
This study aims to answer two problems: first, how is the concept of implementing a bargaining system in the criminal justice system in the United States? Second, what is the urgency of implementing the Plea Bargaining System in reforming the criminal justice system in Indonesia. The research method used is juridical normative with a conceptual approach and comparison method. This paper intends to provide legal problem solving for the accumulation of criminal cases in Indonesia, namely by implementing a plea bargaining system in reforming the criminal justice system in Indonesia. This study concludes that, first, In the United States, the plea bargaining mechanism is carried out at the arraignment and preliminary hearing stages. Second, the plea bargaining system in the United States is regulated in the Federal Rules of Criminal Procedure rule 11. The urgency of implementing a plea bargaining system in the criminal justice system in Indonesia can be seen from several considerations, namely philosophical, juridical, sociological, and political-legal considerations. The conclusions and recommendations of the authors are implementing a plea bargaining system in reforming the criminal justice system in Indonesia in order to realize an effective and efficient criminal justice.
\end{abstract}

Key Worsd: Legal problem solving; plea bargaining; cases

Abstrak

Penelitian ini bertujuan menjawab dua permasalahan yakni pertama, bagaimana konsep penerapan plea bargaining system dalam sistem peradilan pidana di Amerika Serikat? Kedua, bagaimana urgensi penerapan Plea Bargaining System dalam pembaruan sistem peradilan pidana di Indonesia. Metode penulisan yang digunakan adalah yuridis normatif dengan metode pendekatan konseptual dan perbandingan. Tulisan ini hendak memberikan legal problem solving atas permasalahan penumpukan perkara pidana di Indonesia, yakni dengan menerapkan plea bargaining system dalam pembaruan sistem peradilan pidana di Indonesia. Penelitian ini menyimpulkan, pertama, di Amerika Serikat, mekanisme plea bargaining dilakukan pada tahap arraignment dan preliminary hearing. Kedua, Plea bargainning system di Amerika Serikat diatur dalam Federal Rules of Criminal Procedure rule 11. Urgensi menerapkan plea bargaining system dalam sistem peradilan pidana di Indonesia dapat dilihat dari beberapa pertimbangan, yakni pertimbangan secara filosofis, yuridis, sosiologis, dan politik hukum. Kesimpulan dan rekomendasi penulis yakni menerapkan plea bargaining system dalam pembaruan sistem peradilan pidana di Indonesia guna terwujudnya peradilan pidana yang efektif dan efisien.

Kata-kata Kunci: Legal problem solving; plea bargaining; perkara 


\section{Pendahuluan}

Berbagai permasalahan yang ada dalam sistem peradilan pidana di Indonesia belum mampu terpecahkan hingga hari ini, seperti lamanya proses penyelesaian perkara, tingginya biaya dalam penyelesaian perkara, serta menumpuknya perkara pidana di berbagai tingkat pengadilan. Permasalahan penumpukan perkara pada lingkup sistem peradilan pidana di Indonesia terlihat pada fakta penumpukan perkara pidana di pengadilan setiap tahunnya. Pada 2018 misalnya, masih terdapat sisa perkara pada 2017 yang masih harus diselesaikan. Secara keseluruhan, tersisa 132.070 perkara pada 2017 yang harus diselesaikan pada 2018, ditambah lagi perkara baru yang masuk pada tahun berjalan, 2018, yaitu 6.123.197 sehingga jumlah beban perkara yang harus diselesaikan Mahkamah Agung dan badan peradilan di bawahnya pada 2018 sejumlah 6.255.267. Hingga akhir 2018, masih terdapat perkara yang belum mampu tertuntaskan yaitu 133.813 perkara, yang kembali harus dituntaskan pada tahun selanjutnya yaitu pada 2019. Hal tersebut berimplikasi pada beban pada peradilan untuk penyelesaian perkara di tahun selanjutnya. ${ }^{1}$

Data tersebut menunjukkan bahwa proses penyelesaian perkara dalam sistem peradilan pidana di Indonesia berjalan kurang efektif dan efisien. Lamanya proses peradilan pidana di Indonesia hingga hari ini mengakibatkan prinsip pelaksanaan peradilan yang sederhana, cepat, dan biaya ringan sebagaimana amanat Pasal 4 ayat (2) Undang-Undang Nomor 48 Tahun 2009 tentang Kekuasaan Kehakiman² belum mampu diwujudkan. Hal tersebut berimplikasi pada tidak adanya kepastian hukum dan keadilan yang diperoleh terdakwa dalam setiap proses peradilannya.

Terdapat beberapa sistem yang telah diterapkan untuk mewujudkan peradilan pidana yang efektif dan efisien di Indonesia. Pertama, dapat ditemukan pada ketentuan Pasal 10A Undang-Undang Nomor 31 Tahun 2014 tentang Perubahan atas Undang-Undang Nomor 13 Tahun 2006 tentang Lembaga Perlindungan Saksi dan Korban. Kedua, whistleblower yang termuat dalam Surat Edaran Mahkamah Agung

\footnotetext{
1 Mahkamah Agung Republik Indonesia, Laporan Tahunan Mahkamah Agung RI Tahun 2018. http://mahkamahagung.go.id, 2019, Diakses pada tanggal 2 Juli 2020

2 Pasal 4 ayat (2) Undang-Undang Bomor 48 Tahun 2009 tentang Kekuasaan Kehakiman menyatakan bahwa "Pengadilan membantu pencari keadilan dan berusaha mengatasi segala hambatan dan rintangan untuk dapat tercapainya peradilan yang sederhana, cepat, dan biaya ringan."
} 
(SEMA) Nomor 4 Tahun 2011 tentang Perlakuan Bagi Pelapor Tindak Pidana (Whistleblower) dan Saksi Pelaku yang Bekerjasama (Justice Collaborators) di dalam Perkara Tindak Pidana Tertentu yang pada pokoknya dalam SEMA tersebut hanya memberikan pedoman terhadap penanganan kasus yang melibatkan Pelapor Tindak Pidana (Whistleblower). Ketiga, justice collaborator, pengertian dari konsep tersebut termuat dalam SEMA Nomor 4 Tahun 2011 tentang Perlakuan Bagi Pelapor Tindak Pidana (Whistleblower) dan Saksi Pelaku yang Bekerjasama (Justice Collaborator) di dalam Perkara Tindak Pidana Tertentu, namun demikian dalam pelaksanaannya beberapa sistem di atas belum mampu terlaksana dengan maksimal dikarenakan tidak ada aturan yang secara rinci mengatur mekanisme pelaksanaan dari sistem tersebut terutama terkait perlindungan dan penghargaan yang dapat diberikan, ${ }^{3}$ sehingga menurut hemat penulis sistem-sistem tersebut belum mampu mengatasi permasalahan penumpukan perkara serta belum mampu mewujudkan peradilan pidana yang efektif dan efisien.

Dari kondisi tersebut perlu adanya legal problem solving yang dituangkan dalam pembaruan sistem peradilan pidana di Indonesia yang bersumber dari evaluasi terhadap sistem yang ada saat ini. Bentuk pembaruan tersebut yakni dengan pengadopsian sistem baru yang akan diterapkan dalam sistem peradilan pidana di Indonesia yang diyakini dapat mewujudkan proses peradilan pidana yang lebih efektif dan efisien. Sitem baru tersebut adalah dengan menerapkan Plea Bargaining System.

\section{Black's Law Dictionary menyatakan bahwa}

"Plea bargaining is the process whereby the accused and the prosecutor in a criminal case work out a mutually satisfactory disposition of the case subject to the court approach. It usually involves the defendant's pleading guilty to lesser offense or to only one or some of the counts of multi counts indictment in return for a lighter sentence than that possible for the graver charge". 4

Plea Bargaining Sytem merupakan suatu negosiasi antara penuntut umum dengan tertuduh atau pembelanya. Motivasi utamanya adalah untuk mempercepat proses penyelesaian perkara pidana sehingga proses penyelesaian

3 Rusli Muhammad, "Pengaturan Whistle Blower dan Justice Collaborator dalam Sistem Peradilan Pidana”, Jurnal Hukum Ius Quia Fakultas Hukum Universitas Islam Indonesia, Volume 2, Nomor 2, 2015, hlm. 221.

${ }^{4}$ Black's Law Dictionary, Edisi Kesebelas., West Publishing Company, 2010, hlm. 1037. 
perkara pidana akan berjalan efektif dan efisien. Negosiasi harus dilandaskan pada kesukarelaan tertuduh untuk mengakui perbuatannya dan kesediaan dari penuntut umum untuk memberikan ancaman hukuman yang lebih ringan. ${ }^{5}$

Plea Bargaining System telah diterapkan di beberapa negara dan terbukti mampu mengatasi banyaknya perkara yang masuk serta mampu mencegah keluarnya biaya yang tinggi dan waktu yang panjang dalam proses penyelesaian perkara pidana. Salah satu negara yang telah menerapkan Plea Bargaining System adalah Amerika Serikat. 95\% perkara pidana di Amerika Serikat mampu diselesaikan melalui mekanisme Plea Bargaining sehingga peradilan pidana di Amerika Serikat mampu mewujudkan peradilan pidana yang efektif dan efisien. ${ }^{6}$

\section{Rumusan Masalah}

Berdasarkan latar belakang tersebut, penulis ingin menggali lebih dalam mengenai, pertama, bagaimana konsep penerapan Plea Bargaining System dalam sistem peradilan pidana di Amerika Serikat? Kedua, bagaimana urgensi penerapan Plea Bargaining System dalam pembaruan sistem peradilan pidana di Indonesia?

\section{Tujuan Penelitian}

Penyusunan penelitian ini bertujuan sebagai berikut: pertama, untuk memahami, mengkaji, dan menganalisis konsep Plea Bargaining System dalam sistem peradilan pidana di Amerika Serikat sebagai pedoman konsep penerapan Plea Bargaining System di Indonesia; Kedua, untuk menemukan, mengidentifikasi, dan menganalisis urgensi Plea Bargaining System bagi pembaruan sistem peradilan pidana di Indonesia dalam mewujudkan peradilan yang efektif dan efisien.

\section{Metode Penelitian}

Penelitian ini adalah penelitian hukum normatif atau penelitian hukum kepustakaan dengan menggunakan metode pendekatan konseptual dan perbandingan. Teknik pengumpulan bahan hukum yang dilakukan adalah model studi kepustakaan (library research), karena itu data yang digunakan adalah data sekunder yang terdiri dari bahan hukum primer dan bahan hukum sekunder.

\footnotetext{
5 The Federal of Criminal Procedure Rule 11.

${ }^{6}$ Romli Atmasasmita, Sistem Peradilan Pidana Kontemporer, Kencana Prenada Media Grup, Jakarta, 2010, hlm. 119.
} 
Semua bahan hukum yang telah dikumpulkan tersebut akan dianalisis secara deskriptif kualitatif dengan menekankan pada penalaran, yang akan membandingkan sistem peradilan pidana di Indonesia dan Amerika Serikat sehingga akan ditemukan urgensi dari penerapan plea bargaining system dalam sistem peradilan pidana di Indonesia.

\section{Hasil Penelitian dan Pembahasan}

\section{Plea Bargaining dalam Sistem Peradilan Pidana di Amerika Serikat}

Albert Alschuler menyatakan, plea bargaining muncul pada pertengahan abad ke-19 dan awal abad ke-20.7 Sistem ini berperan dalam mengatasi kesulitan menangani perkara pidana dan pengadilan di Amerika Serikat sangat bergantung pada sistem ini pada 1930.8 Pada praktik plea bargaining system di Amerika Serikat, jika melihat statistik dari United States Departement of Justice pada 2000, sebanyak $87,1 \%$ terdakwa melakukan mekanisme plea bargaining, sementara hanya 12,9\% melanjutkan ke pengadilan. ${ }^{9}$ Supreme Court Amerika Serikat telah menyatakan mekanisme plea bargaining adalah elemen esensial dan diinginkan dalam sistem peradilan pidananya. ${ }^{10}$ Sebanyak $95 \%$ dakwaan di Amerika serikat diselesaikan dengan pengakuan bersalah dari terdakwa. ${ }^{11}$ Dari data tersebut dapat dilihat tingginya tingkat keberhasilan penerapan plea bargaining system di Amerika Serikat dalam menangani perkara pidana yang masuk ke pengadilan.

Terdapat beberapa tahap proses dalam penanganan perkara pidana pada sistem peradilan pidana di Amerika Serikat yakni dimulai dari penyidikan, penuntutan, pemeriksaan dalam sidang, penetapan hukuman dan pelaksanaan hukumannya. Dalam sistem peradilan pidana di Amerika Serikat, plea bargaining terjadi pada tahap sebelum pemeriksaan persidangan yakni pada tahap preliminary hearing dan arraignment. Apabila seorang tertuduh menyatakan

\footnotetext{
7 Albert Alschuler, "Plea Bargaining and Its History", Journal Articles University of Chichago Law School, Volume79, Nomor 1, 1979, hlm. 351.

${ }^{8}$ Langbein, "Understanding the Short History of Plea Bargaining", Yale Law Achool Legal Scholarship Repository, Rev. 261, 1979, hlm. 254.

9 Misha, "Issues of Overcrowded Prisons and The Trade-Off "Plea Bargaining in the Criminal Justice", dalam http://www.associatedcontent.com, 2005.

10 Sidhartha Mohapatra \& Hailshree Saksena, Plea Bargain: A Uniqie Remedy, http://indlaw.com, New York, 2009.

${ }^{11}$ Igor and Ivana, "Plea Bargaining: A Challenging Issue in the Law and Economics", Faculty Of Law , J.J. Strossmayer University of Osijek, 2010, hlm. 113.
} 
dirinya bersalah atas kejahatan yang dilakukan, maka proses selanjutnya adalah penjatuhan hukuman tanpa melalui trial. ${ }^{12}$

Periode arraignment on information or indictment merupakan suatu proses singkat guna mencapai tujuan yaitu memberitahukan kepada tertuduh perihal tuduhan yang dijatuhkan kepadanya dan memberikan kesempatan pada tertuduh untuk menjawab tuduhan tersebut. Jika tertuduh menyatakan not guilty, maka perkara dilanjutkan dan kemudian diadili di muka persidangan oleh juri. Apabila tertuduh menyatakan guilty atau nolo contendence (no-contest), maka perkaranya siap untuk diputus. Khususnya pernyataan nolo contendence (nocontest), pada hakikatnya ini memiliki implikasi yang sama dengan pernyataan guilty, tetapi dalam hal ini tidak disyaratkan bahwa tertuduh harus mengakui kesalahannya. Tertuduh cukup menyatakan bahwa dia tidak akan menentang tuduhan jaksa di muka persidangan nanti. ${ }^{13}$

Plea bargaining dilakukan dengan suatu plea guilty dari terdakwa dengan imbalan dakwaan yang diperingan dan/atau tuntutan pidana yang diperingan. Dengan proses ini, hakim tidak lagi melakukan pemeriksaan di sidang dan segera dapat menjatuhkan pidana. Maka dari itu, plea bargaining dianggap cost effective dan mengurangi beban kejaksaan dan pengadilan. ${ }^{14}$

Pengaturan mengenai plea bargainning system di Amerika Serikat diatur dalam Federal Rules of Criminal Procedure, khususnya dalam rule 11. Federal Rules of Criminal Procedure rule 11 sub (d) yang melarang pengadilan untuk menerima pengakuan bersalah tanpa terlebih dahulu mendengar keterangan si terdakwa mengenai apakah pengakuan yang ia buat dilakukan secara sukarela dan bukan dikarenakan tekanan atau paksaan atau janji lain yang diberikan penuntut umum di luar yang terdapat dalam Plea Agreement. Untuk melindungi dari kesewenangwenangan yang dilakukan penuntut umum dalam melakukan plea bargaining, ditentukan juga bahwa pengadilan tidak akan memberikan putusan terkait pengakuan bersalah sebelum adanya penyelidikan yang cukup bahwa ada dasar faktual (factual basis) dalam melakukan plea bargaining. Apabila ketentuan ini

12 The Federal of Criminal Procedure Rule 11.

13 Romli Atmasasmita, Op. Cit., hlm. 123-124

14 M Lutfi Chakim, "Plea Bargaining", dalam http://www.lutfichakim.com, diakses pada 5 Januari 2020. 
dilanggar, maka Plea Agreement yang sudah dibuat tidak dapat diterima oleh pengadilan dan proses peradilan dilanjutkan ke tahapan persidangan. ${ }^{15}$

Berdasarkan uraian di atas, penulis akan menuangkan dalam bentuk matrik guna memberikan gambaran terkait mekanisme penerapan plea bargaining system di Amerika Serikat untuk memudahkan pembaca memahami mekanisme pelaksanaan plea bargaining system.

\section{Bagan 1}

Mekanisme plea bargaining system di Amerika Serikat

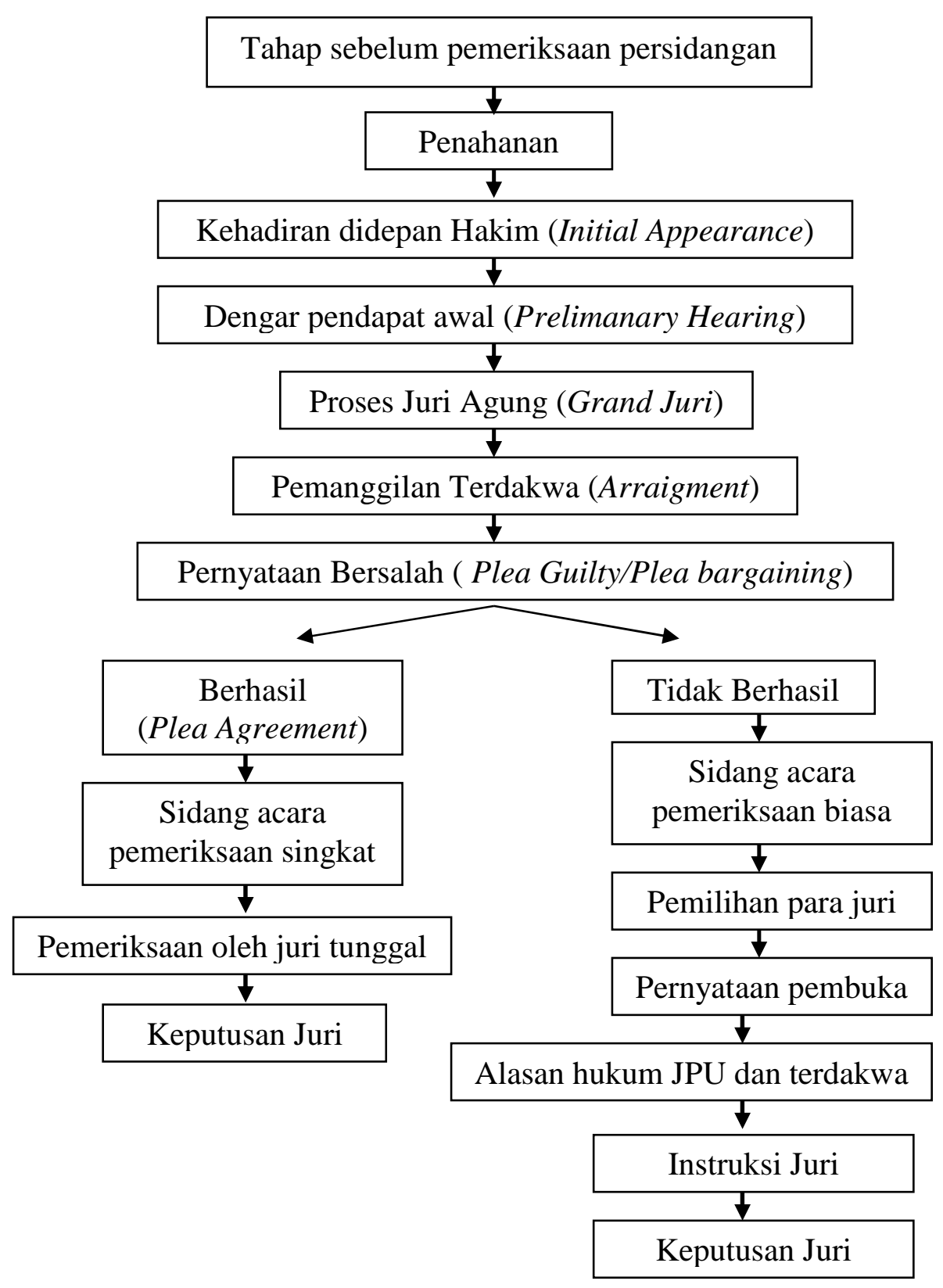

Sumber: The Federal of Criminal Procedure rule 11, yang diolah oleh Penulis (2020

15 The Federal of Criminal Procedure Rule 11. 
Urgensi Plea Bargaining dalam Pembaruan Sistem Peradilan Pidana di Indonesia

\section{Alasan Filosofis}

Pasal 28D ayat (1) UUD NRI 1945 menyatakan bahwa "setiap orang berhak atas pengakuan, jaminan, perlindungan, dan kepastian hukum yang adil serta perlakuan yang sama di hadapan hukum." Sesuai dengan ketentuan tersebut, rakyat Indonesia berhak untuk mendapatkan kepastian hukum yang adil serta perlakuan yang sama di hadapan hukum dalam setiap proses kehidupannya, salah satunya sebagaimana fokus penulis dalam tulisan ini bahwasanya setiap orang yang menjadi tersangka/terdakwa dalam suatu tindak pidana wajib mendapatkan kepastian hukum yang adil dalam setiap proses/tahap-tahap penyelesaian perkara pidananya. Salah satunya adalah hak untuk mendapatkan kepastian hukum dari keberlanjutan kasus yang dialaminya.

Proses peradilan pidana yang baik tentunya dapat melaksanakan suatu proses peradilan pidana dengan cepat, sederhana, dan biaya ringan, yang tetap memperhatikan nilai-nilai keadilan didalamnya. Sebagaimana penulis kutip dari M. Najih, “hukum yang bersifat progresif harus mewujudkan rasa keadilan dalam masyarakat."16 Karena, jika suatu proses peradilan pidana dilakukan secara cepat dan sederhana, tentunya setiap orang yang menjadi tersangka/terdakwa dalam suatu tindak pidana tertentu juga akan mendapatkan kepastian hukum dalam proses dan keberlanjutan dari perkara yang dialaminya. Hal tersebut akan berimplikasi pada biaya yang akan dikeluarkan oleh para pihak yang berperkara dalam proses peradilannya, yakni akan menghasilkan proses peradilan pidana dengan biaya ringan.

Hukum dibentuk untuk manusia, bukan sebaliknya manusia untuk hukum. Dalam norma-norma berkaitan dengan pembaruan proses peradilan pidana di Indonesia, juga perlu memperhatikan kebutuhan yang ada saat ini yang belum mampu terselesaikan. ${ }^{17}$ Sebagaimana pendapat John Rawls, beliau berpendapat bahwa keadilan adalah kebajikan utama dari hadirnya institusi-institusi sosial

\footnotetext{
${ }^{16}$ Muhammad Najih, Politik. Hukum Pidana: Konsepsi Pembaruan Hukum Pidana dalam Cita Negara Hukum, Setara Press, Malang, 2014, hlm. 34. hlm. 30 .

17 Satjipto Rahardjo, Negara Hukum yang Membahagiakan Rakyatnya, Genta Publishing, Yogyakarta, 2008,
} 
(social institutions). Akan tetapi, menurut Rawls, kebaikan bagi seluruh masyarakat tidak dapat mengesampingkan atau menggangu rasa keadilan dari setiap orang yang telah memperoleh rasa keadilan, khususnya masyarakat lemah. Secara spesifik, Rawls mengembangkan gagasan mengenai prinsip-prinsip keadilan dengan menggunakan sepenuhnya konsep ciptaannya yang dikenal dengan "posisi asali" (original position) dan "selubung ketidaktahuan" (veil of ignorance). Rawls berusaha untuk memosisikan adanya situasi yang sama dan setara antara tiap-tiap orang di dalam masyarakat serta tidak ada pihak yang memiliki posisi lebih tinggi antara satu dengan yang lainnya, seperti misalnya kedudukan, status sosial, tingkat kecerdasan, kemampuan, kekuatan, dan lain sebagainya. Sehingga, orang-orang tersebut dapat melakukan kesepakatan dengan pihak lainnya secara seimbang.

Kondisi demikianlah yang dimaksud oleh Rawls sebagai "posisi asali" yang bertumpu pada pengertian ekulibrium reflektif dengan didasari oleh ciri rasionalitas (rationality), kebebasan (freedom), dan persamaan (equality) guna mengatur struktur dasar masyarakat (basic structure of society). ${ }^{18}$ Teori ini bermakna bahwa persamaan/equality harus dapat diterapkan dalam penegakan hukum untuk mewujudkan keadilan, salah satunya yakni keadilan sosial. Diberikannya suatu ruang untuk menyelesaikan suatu perkara pidana melewati mekanisme penyelesaian perkara di luar persidangan dalam tindak pidana tertentu adalah suatu model yang perlu diberikan dalam pembentukan norma baru hukum acara pidana sebagai upaya pembaruan sistem peradilan pidana di Indonesia untuk terwujudnya keadilan sosial bagi seluruh rakyat Indonesia.

\section{Alasan Yuridis}

Pasal 28D ayat (1) UUD NRI 1945 menjelaskan bahwa "setiap warga Negara Indonesia berhak mendapatkan kepastian hukum yang adil serta perlakuan yang sama di hadapan hukum." Makna dari ketentuan tersebut melingkupi pemaknaan bahwa setiap orang yang menjadi tersangka/terdakwa dalam suatu tindak pidana wajib mendapatkan kepastian hukum yang adil dalam setiap proses/tahap-tahap penyelesaian perkara pidananya, salah satunya hak untuk 138-139.

18 Pan Mohamad Faiz, “Teori Keadilan John Rawls" Jurnal Konstitusi, Volume 6, Nomor 1, 2009, hlm. 
mendapatkan kepastian hukum dari keberlanjutan kasus yang dialaminya. Hal tersebut selaras dengan Pasal 4 ayat (2) Undang-Undang No. 48 Tahun 2009 tentang Kekuasaan Kehakiman yang mengamanatkan bahwa proses peradilan harus dilakukan secara sederhana, cepat, dan biaya ringan, namun berdasarkan permasalahan yang telah penulis uraikan dalam sub bab sebelumnya, pelaksanaan proses peradilan pidana hingga hari ini belum dapat mewujudkan proses peradilan yang sederhana, cepat, dan biaya ringan. Saat ini, rumitnya proses peradilan pidana di Indonesia mengakibatkan pelaksanaa peradilan yang sederhana, cepat, dan biaya ringan tidak mampu diwujudkan dalam proses peradilan pidana di Indonesia. Sehingga dalam hal ini perlu adanya pembaruan sistem peradilan pidana di Indonesia. Hal tersebut merupakan landasan yuridis urgensi penerapan Plea Bargaining di Indonesia.

\section{Alasan Sosiologis}

Sistem peradilan pidana di Indonesia sebenarnya telah mengenal konsep semacam plea bargaining" sebagai upaya untuk mewujudkan peradilan pidana yang efektif dan efisien, antara lain: pertama, dapat ditemukan pada ketentuan Pasal 10A Undang-Undang Nomor 31 Tahun 2014 tentang Perubahan atas Undang-Undang Nomor 13 Tahun 2006 tentang Lembaga Perlindungan Saksi dan Korban (UU LPSK). Pada pokoknya, ketentuan tersebut bermaksud memberikan keringanan kepada saksi yang juga tersangka dalam kasus yang sama sehingga kesaksiannya dapat dijadikan pertimbangan hakim dalam meringankan pidana yang akan dijatuhkan, namun pengaturan mengenai ketentuan tersebut belum secara rinci mengatur bagaimana perlindungan dan penghargaan yang dapat diberikan kepada saksi/korban. ${ }^{19}$

Kedua, whistleblower yang termuat dalam SEMA Nomor 4 Tahun 2011 tentang Perlakuan Bagi Pelapor Tindak Pidana (Whistleblower) dan Saksi Pelaku yang Bekerjasama (Justice Collaborators) di dalam Perkara Tindak Pidana Tertentu yang pada pokoknya dalam SEMA tersebut hanya memberikan pedoman terhadap penanganan kasus yang melibatkan Pelapor Tindak Pidana (Whistleblower). Dalam SEMA tersebut dijelaskan bahwa seseorang dapat

${ }^{19}$ Rusli Muhammad, Op. Cit., hlm. 221. 
dikatakan whistleblower apabila pelapor merupakan pihak yang mengetahui dan melaporkan tindak pidana pidana tertentu dan bukan bagian dari pelaku kejahatan yang dilaporkannya. Secara yuridis normatif, berdasar pada Pasal 10A UU LPSK, keberadaan whistleblower tidak ada tempat untuk mendapatkan perlindungan secara hukum. Bahkan, seorang saksi yang juga tersangka dalam kasus yang sama tidak dapat dibebaskan dari tuntutan pidana apabila ia ternyata terbukti secara sah dan meyakinkan bersalah, tetapi kesaksiannya dapat dijadikan pertimbangan hakim dalam meringankan pidana yang akan dijatuhkan. Mardjono Reksodiputro, menyebut ini sebagai pembocor rahasia atau pengadu. ${ }^{20}$ Oleh karena itu, dalam praktiknya, whistleblower terkadang juga terlibat dan memiliki peran yang kecil dalam kejahatan tersebut sehingga ini tidak efektif. ${ }^{21}$

Ketiga, justice collaborator (saksi pelaku yang bekerja sama). Konsep tersebut juga termuat dalam SEMA Nomor 4 Tahun 2011 tentang Perlakuan Bagi Pelapor Tindak Pidana (Whistleblower) dan Saksi Pelaku yang Bekerjasama (Justice Collaborator) di dalam Perkara Tindak Pidana Tertentu yang pada pokoknya dalam SEMA tersebut hanya memberikan pedoman terhadap penanganan kasus yang melibatkan justice collaborator. Dalam SEMA tersebut dijelaskan bahwa seseorang dapat dikatakan justice collaborator apabila yang bersangkutan merupakan salah satu pelaku tindak pidana pidana tertentu dan mengakui kejahatan yang dilakukannya dan bukan merupakan pelaku utama dalam kejahatan tersebut serta yang bersangkutan memberikan keterangan sebagai saksi di dalam proses peradilan. whistleblower dan justice collaborator merupakan hal yang serupa dengan plea bargaining system, hal terseburt terlihat bahwa dalam whistleblower, justice Collaborator dan plea bargaining system ketiganya merupakan bentuk pengakuan/memberikan keterangan dalam suatu tindak pidana untuk tujuan tertentu. Namun antara ketiganya jelas berbeda dalam praktik dan keefektifannya dalam mewujudkan peradilan yang efektif dan efisien. ${ }^{22}$

\footnotetext{
${ }^{20}$ Mardjono Reksodiputro, Pembocor Rahasia/Wistle Blowers dan Penyadapan (Wiretapping, Electronic Interception) Dalam Menanggulangi Kejahatan Di Indonesia, Wacana Goverminyboard, hlm. 13.

${ }^{21}$ Nixson dan Syafrudin Kalo, "Perlindungan Hukum terhadap Whistleblower dan Justice Collaborator dalam Upaya Pemberantasan Tindak Pidana Korupsi”, USU Law Journal, Volume II, Nomor 2, 2013, hlm. 41.

${ }^{22}$ Lilik Mulyadi, "Menggagas Konsep dan Model Ideal Perlindungan Hukum Terhadap Whistleblower dan Justice Collaborator dalam Upaya Penanggulangan Organized Crime di Indonesia Masa Mendatang", Jurnal Hukum dan Peradilan, Volume III, Nomor 2, 2014, hlm. 101-105.
} 
Keempat, diskresi yang dilakukan oleh Penyidik Kepolisian. Pengaturan mengenai diskresi ini termaktub dalam Pasal 18 ayat (1) Undang-Undang Nomor 2 Tahun 2002 tentang Kepolisian Negara Republik Indonesia, "untuk kepentingan umum pejabat Kepolisian Negara Republik Indonesia dalam melaksanakan tugas dan wewenangnya dapat bertindak menurut penilaiannya sendiri." Diskresi dimaknakan sebagai kemerdekaan dan/atau kewenagan dalam membuat keputusan untuk mengambil tindakan yang dianggap tepat atau sesuai dengan situasi dan kondisi yang dihadapi secara bijaksana dan dengan memperhatikan segala pertimbangan dan pilihan yang memungkinkan. Diskresi diartikan sebagai kebebasan mengambil keputusan dalam setiap situasi yang dihadapi menurut pendapatnya sendiri. Dalam istilah yang lebih sederhana, diskresi adalah hak untuk melakukan seleksi perkara. Dalam hal ini, diskresi dilakukan atas subyektivitas dari kepolisian sendiri untuk menilai suatu perkara dapat dilanjutkan ke persidangan atau tidak, sehingga tidak terdapat kepastian hukum yang jelas mengenai pelaksanaan diskresi tersebut. ${ }^{23}$

Kondisi sosiologis yang lain adalah terdapat berbagai permasalahan dalam proses pelaksanaan peradilan pidana di Indonesia yakni seperti lamanya proses penyelesaian perkara, tingginya biaya dalam penyelesaian perkara, serta menumpuknya perkara pidana di pengadilan yang tak kunjung usai. Permasalahan penumpukan perkara pada lingkup sistem peradilan pidana di Indonesia terlihat pada data yang penulis peroleh dari Website atau laman resmi Mahkamah Agung. ${ }^{24}$ Data tersebut menunjukkan pada 2018 terdapat sisa perkara pada 2017 yang masih harus diselesaikan pada tahun berikutnya, yaitu 2018. Secara keseluruhan, pada 2017, 132.070 perkara tersisa sehingga harus diselesaikan pada 2018, ditambah lagi perkara baru yang masuk pada 2018, yaitu 6.123.197 perkara. Dengan demikian, jumlah beban perkara yang harus diselesaikan Mahkamah Agung dan badan peradilan dibawahnya pada 2018 sejumlah 6.255.267. Pada 2019, masih terdapat sisa perkara yang belum mampu tertuntaskan pada 2018, yaitu 133.813 perkara yang kembali harus dituntaskan

\footnotetext{
${ }^{23}$ Son Haji dan Gunarto, "Implementasi Kewenangan Diskresi Kepolisian dalam Penanganan Tindak Pidana di Polres Demak Jawa Tengah”, Jurnal Hukum Khaira Ummah, Volume 13, Nomor 1, 2018., hlm. 55.

24 Mahkamah Agung Republik Indonesia, Laporan Tahunan Mahkamah Agung RI Tahun 2018. http://mahkamahagung. go. id, 2019, diakses pada 2 Juli 2020.
} 
pada tahun berjalan, yaitu 2019. Data tersebut menandakan bahwa sistem peradilan pidana di Indonesia hari ini belum efektif dan efisien. ${ }^{25}$

\section{Alasan Politik Hukum}

Hukum bukan merupakan institusi yang mutlak serta final, karena hukum selalu berada dalam proses untuk terus menjadi (law as a process, law in the making), sehingga perlu adanya pembaruan di bidang hukum untuk mewujudkan tujuan hukum. ${ }^{26}$ Semangat pembaruan hukum yang ada di Indonesia saat ini merupakan eforia untuk menciptakan kondisi lebih baik dibidang pembangunan hukum. Sunaryati Hartono mengemukakan bahwa hukum sebagai alat yang merupakan sarana dan langkah yang dilakukan oleh pemerintah untuk menciptakan sistem hukum nasional guna mencapai cita-cita bangsa dan tujuan negara. ${ }^{27}$

Mochtar Kusumaadmadja menyatakan, bahwa pembaruan dapat diwujudkan melalui perundang-undangan atau keputusan pengadilan atau kombinasi keduanya, dan "hukum harus menjadi sarana pembangunan" yang nanti pada tahap selanjutnya diintroduksi menjadi kebijakan pembangunan hukum nasional. ${ }^{28}$ Pembaruan hukum pidana merupakan salah satu upaya untuk mewujudkan kesejahteraan sosial serta sebagai upaya untuk mewujudkan tujuan dari hukum itu sendiri. Politik hukum pidana merupakan suatu alat yang digunakan oleh negara untuk mencapai tujuan dan fungsi hukum dalam masyarakat. Sebagaimana merujuk pada pendapat Sunaryati Hartono dan Mahfud MD, penulis kutip dari M.Najih, bahwa "politik hukum harus ditempatkan sebagai alat yang bekerja dalam sistem sosial dan sistem hukum tertentu untuk mencapai suatu tujuan masyarakat atau negara." 29

Pembaruan hukum pidana pada dasarnya merupakan bagian dari kebijakan hukum pidana. ${ }^{30}$ Sebagai bagian dari kebijakan hukum pidana, pembaruan

${ }_{25}$ Menurut Kamus Besar Bahasa Indonesia (selanjutnya disebut KBBI) efisien yaitu tepat atau sesuai untuk mengerjakan (menghasilkan) sesuatu (dengan tidak membuang waktu, tenaga, biaya); mampu menjalankan tugas dengan tepat dan cermat; berdaya guna; bertepat guna.

${ }^{26}$ Kusumaadmadja, Mochtar, Konsep-konsep Hukum Dalam Pembangunan, Alumni, Bandung, 2002, hlm. 53

${ }^{27}$ Mahfud MD, Politik. Hukum, PT. Raja Grafindo Persada. Jakarta, 2009, hlm. 2.

28 Shidarta, Mochtar Kusumaatmadja dan Teori Hukum Pembangunan. Epistema Institute, Jakarta, 2012, hlm. 89.

${ }^{29}$ Muhammad Najih, Op. Cit., hlm. 48 2010, hlm. 19.

${ }^{30}$ Barda Nawawi dalam Tongat, Hukum Pidana Indonesia: Dalam Prespektif Pembaruan, UMM Press, Malang, 
hukum pidana hakikatnya bertujuan untuk menjadikan hukum pidana lebih baik sesuai dengan nilai-nilai yang ada dalam masyarakat. Dalam konteks Indonesia, pembaruan hukum pidana dilakukan sebagai strategi untuk menciptakan hukum yang paling baik yang untuk mengatur, memelihara, dan menjaga konsistensi terwujudnya ide dan cita negara, pun juga agar hukum pidana yang berlaku sesuai dengan nilai-nilai yang dimiliki masyarakat Indonesia. ${ }^{31}$

Muhammad Najih dalam bukunya "Politik Hukum Pidana" menggolongkan politik hukum pidana dalam beberapa bentuk cabang dan cakupan politik hukum pidana salah satunya yakni kebijakan peradilan pidana (judicial criminal policy). ${ }^{32}$ Hal ini sejalan dengan urgensi pembaharuan sistem peradilan pidana untuk mewujudkan peradilan pidana yang efktif dan efisien. Berbagai permasalahan dalam proses pelaksanaan peradilan pidana di Indonesia yakni seperti lamanya proses penyelesaian perkara, tingginya biaya dalam penyelesaian perkara, serta menumpuknya perkara pidana di pengadilan yang tidak kunjung usai. Pembaruan tersebut yakni dengan menerapkan plea bargaining dalam sistem peradilan pidana di Indonesia.

Penulis membandingkan sistem peradilan pidana yang ada di Amerika Serikat dengan sistem peradilan pidana di Indonesia yang mana hal tersebut untuk penyelarasan adopsi konsep penerapan plea bargaining. Dalam perbandingan hukum dikenal adanya dua keyakinan tentang unsur yang mendasari terjadinya adopsi hukum. Salah satunya adalah bahwa adopsi hukum dapat terjadi meskipun ada perbedaan antara sistem hukum yang dijadikan model untuk ditiru dengan sistem hukum penerima. Zweigert dan Kotz menegaskan pendapat Rudolf Jhering, penulis kutip dari Sundari, bahwa: ${ }^{33}$

“....adopsi hukum asing ke suatu negara bukan merupakan masalah nasionalitas, akan tetapi lebih pada masalah bagaimana kegunaan dari sistem hukum yang akan ditiru dan kebutuhan dari negara yang akan menerima. Tak seorangpun akan mengadopsi hukum dari tempat yang jauh apabila di tempat sendiri sudah baik dan sebaliknya, akan terlihat bodoh apabila ada bunga yang indah tidak mau diambil hanya karena bukan berasal dari kebun sendiri...."

31 Muhammad Najih, Op. Cit., hlm. 15.

32 Ibid., hlm. 22. hlm. 27

33 Sundari, Perbandingan Hukum dan Fenomena Adopsi Hukum, Cahaya Atma Pustaka, Yogyakarta, 2014, 
Berdasarkan hal tersebut, terlihat jelas bahwa yang dicari dalam melakukan perbandingan hukum adalah nilai-nilai yang tekandung dalam sistem hukum. Dalam hal ini, nantinya akan diambil sesuatu yang dianggap lebih baik dari yang dimiliki sendiri untuk kemudian diadopsi berdasarkan kegunaan dan kebutuhan dari negara penerima. Dengan demikian, menurut hemat penulis, studi perbandingan yang dilakukan antara Amerika Serikat dan Indonesia merupakan hal yang sah, meskipun sistem hukum antara keduanya jelas berbeda. ${ }^{34}$

Penerapan plea bargaining di Amerika Serikat telah membuat peradilan pidana di Amerika Serikat menjadi efektif dan efisien sehingga peradilan pidana di Amerika Serikat mampu mencegah keluarnya biaya yang tinggi dan waktu yang panjang dalam proses peradilan pidananya. Hal tersebut berbanding terbalik dengan proses peradilan pidana di Indonesia yang masih jauh dari predikat peradilan pidana yang "efektif dan efisien", sehingga untuk mewujudkan proses peradilan pidana yang efektif dan efisien perlu adanya perbandingan yang dilakukan dalam rangka mewujudkan peradilan pidana yang efektif dan efisien, yang nantinya akan menghasilkan pengadopsian konsep penerapan plea bargaining di Amerika Serikat untuk diterapkan di Indonesia.

\section{Konsep Penggunaan Plea Bargaining System dalam Sistem Peradilan Pidana di Indonesia}

Penerapan plea bargaining dalam sistem peradilan pidana di Indonesia akan ditekankan dengan beberapa batasan-batasan, yakni plea bargaining akan diberikan kepada terdakwa yang melakukan tindak pidana dengan ancaman hukuman di bawah tujuh tahun. Kesempatan untuk mendapatkan proses plea bargaining akan diberikan kepada terdakwa sebanyak satu kali sehingga bagi terdakwa yang telah melakukan plea bargaining tidak mendapatkan kesempatan untuk diadili menggunakan mekanisme plea bargaining. Pada penerapan gagasan ini, integritas dari penuntut umum sangat diperlukan karena kunci utama berhasilnya plea bargaining system adalah penuntut umum dan terdakwa atau

\footnotetext{
34 Sistem hukum Indonesia baik dalam lapangan hukum pidana, hukum perdata maupun hukum tata negara masih tetap menggunakan sistem hukum dan metoda pendekatan sistem hukum "Civil Law”. Sistem hukum "civil law" menempatkan kodifikasi hukum sebagai sumber hukum satu-satunya didalam praktek penerapan hukum. Berbeda dengan Amerika Serikat yang menerapkan sistem hukum "Common Law" yang menempatkan yurisprudensi sebagai sumber hukum dalam praktek penerapan hukumnya.
} 
penasehat hukumnya. Dalam hal ini, perlu adanya pelatihan sebagai upaya penambahan wawasan kepada penuntut umum mengenai plea bargaining system. Ini demi terwujudnya penuntut umum yang berintegritas untuk proses peradilan pidana yang efektif dan efisien melalui plea bargaining system.

Selanjutnya, pemerintah hendaknya segera membuat regulasi mengenai mekanisme penerapan dari plea bargaining system, mulai dari prosedur pelaksanaan plea bargaining system, jaminan pemenuhan hak-hak yang dimiliki oleh terdakwa pada saat terdakwa melakukan pengakuan bersalahnya, serta batas-batas waktu pelaksanaan mekanisme plea bargaining sebagai upaya mewujudkan kepastian dalam penerapan peradilan yang sederhana, cepat, dan biaya ringan. Diterapkannya Plea Bargaining System di Indonesia diharapkan dapat menekan permasalahan penumpukan perkara serta mampu mewujudkan proses peradilan pidana yang sederhana, cepat, dan biaya ringan. Dengan demikian, tujuan hukum yaitu keadilan, kemanfaatan, dan kepastian hukum dapat terwujud sehingga proses peradilan di Indonesia menjadi lebih efektif dan efisien.

Terdapat pihak-pihak yang bersangkutan dalam penerapan plea bargaining system dalam proses peradilan di Indonesia, antara lain:

\section{Peranan Penuntut Umum}

Peran Jaksa Penuntut Umum dalam pelaksanaan mekanisme plea bargaining sangat penting karena aktor yang memiliki legal standing dalam pelaksanaan sistem ini hanya penuntut umum dan terdakwa atau penasehat hukumnya. Diharapkan, ketika nantinya plea bargaining system diterapkan, diadakan pelatihan dan diberikan pemahaman lebih kepada penuntut umum agar nantinya plea bargaining system dapat berjalan sesuai dengan tujuan yang hendak dicapai, yakni untuk mewujudkan peradilan yang sederhana, cepat, dan biaya ringan, sehingga akan tercipta proses peradilan yang efektif dan efisien.

Penerapan plea bargaining di Indonesia akan ada pada tahap sebelum proses pemeriksaan persidangan. Sebelum memasuki tahapan plea guilty, perlu diperhatikan tiga hal, yaitu mengenai inkompetensi, kapasitas mental si terdakwa dalam melakukan plea guilty, dan apakah si terdakwa pada saat melakukan pengakuan berada dalam kondisi mental yang terganggu atau tidak. Yang 
dimaksud dengan inkompetensi adalah apakah si terdakwa telah cukup dewasa dan rasional untuk mengerti suatu proses persidangan, yang dimaksud dengan kapasitas mental adalah apakah si terdakwa memiliki kapasitas pengetahuan atau pendidikan yang wajar, sedangkan kondisi mental yang terganggu mengacu ke apakah pada saat melakukan plea guilty si terdakwa dalam kondisi sadar dan waras atau tidak.

Penuntut umum juga akan melakukan pemberitahuan kepada terdakwa terkait dengan pengenyampingan hak-haknya berupa:

a. Pengenyampingan hak untuk mengajukan banding;

b. Pengenyampingan hak atas non self incrimination, dengan melakukan pengakuan bersalah atas tindak pidana yang ia akui ia lakukan, namun ia tidak dapat dipaksa untuk memberikan informasi lain yang mungkin melibatkan ia sebagai seorang terdakwa;

\section{Peranan Penasehat Hukum}

Penasehat hukum memiliki kewajiban untuk menjelaskan kepada klien mengenai tahapan plea bargaining, konsekuensi maksimal dari pengakuan tersebut, dan kewajiban untuk mendiskusikan semua penawaran dari penuntut umum. Penasehat hukum harus memperkirakan apakah melakukan plea guilty pada mekanisme plea agreement lebih menguntungkan terdakwa dibanding dengan diadili di muka persidangan. Penasehat hukum juga akan mempertimbangkan mengenai negosiasi yang ditawarkan oleh penuntut umum kepada terdakwa dengan membandingkan negosiasi yang pernah ditawarkan oleh penuntut umum atas kasus yang sama.

\section{Peranan Hakim}

Hakim memiliki peranan paling penting dalam tahapan sesudah plea bargaining yaitu untuk menguji apakah terdakwa melakukan pengakuan dengan sukarela atau tidak. Hakim juga dapat memberi penawaran kepada terdakwa apakah ia akan membatalkan perjanjian-perjanjian yang telah ia buat dalam tahapan plea bargaining atau tidak. Hakim juga harus memperingatkan terdakwa mengenai implikasi dari dilakukannya sebuah plea guilty, yaitu berupa: 
a. Hak terdakwa untuk menolak pengakuannya apabila pengadilan bermaksud untuk melebihi hukuman dibanding dengan hukuman yang direkomendasikan oleh penuntut umum;

b. Memberitahukan terdakwa bahwa dengan pengakuannya ia juga telah mengenyampingkan haknya untuk diadili di persidangan;

c. Memberikan informasi kepada terdakwa mengenai kemungkinan hukuman tertentu;

d. Memastikan bahwa terdakwa mengerti setiap elemen dari Plea Agreement yang ia buat, dan

e. Memastikan bahwa Plea Agreement dibuat secara sukarela, dan proses Plea Bargaining dilakukan dengan factual basis;

f. Memutuskan untuk menerima atau menolak pengakuan si terdakwa.

Peringatan dari pengadilan kepada terdakwa merupakan proses yang sangat penting karena inilah salah satu parameter untuk pengakuan yang diberikan oleh terdakwa, apakah pengakuan dilakukan secara sukarela atau tidak sehingga hak-hak terdakwa tetap terlindungi.

Berikut penulis akan menuangkan dalam bentuk matrik konsep penerapan plea bargaining system dalam proses peradilan pidana di Indonesia guna memberikan gambaran terkait mekanisme penerapan plea bargaining system bagi pembaruan sistem peradilan pidana di Indonesia. 


\section{Bagan 2.}

Mekanisme plea bargaining system dalam sistem peradilan pidana di Indonesia

Sumber: Penulis (2020)

Penyelidikan

Penyidikan (Pasal 106 - Pasal 136 KUHAP)

Penahanan jika ditahan

BAP (Berita Acara Pemeriksaan)

Penyidik menyerahkan BAP kepada Jaksa Penuntut Umum

(Pasal 110 ayat (1) KUHAP)

\section{Prapenuntutan}

Jika JPU berpendapat bahwa BAP dianggap kurang lengkap, maka JPU akan mengembalikan BAP kepada Penyidik. Dalam jangka waktu 14 hari Penyidik harus kembali mengembalikan BAP ke JPU (Pasal 138 ayat (2) KUHAP)

Penuntutan (Pasal 137 - Pasal 144 KUHAP)

Jika Tindak Pidana merupakan Tindak Pidana dengan ancaman hukuman di bawah 7 tahun, maka dilakukannya mekanisme Plea Bargaining yang dilakukan oleh Penuntut Umum dan Terdakwa di luar Persidangan

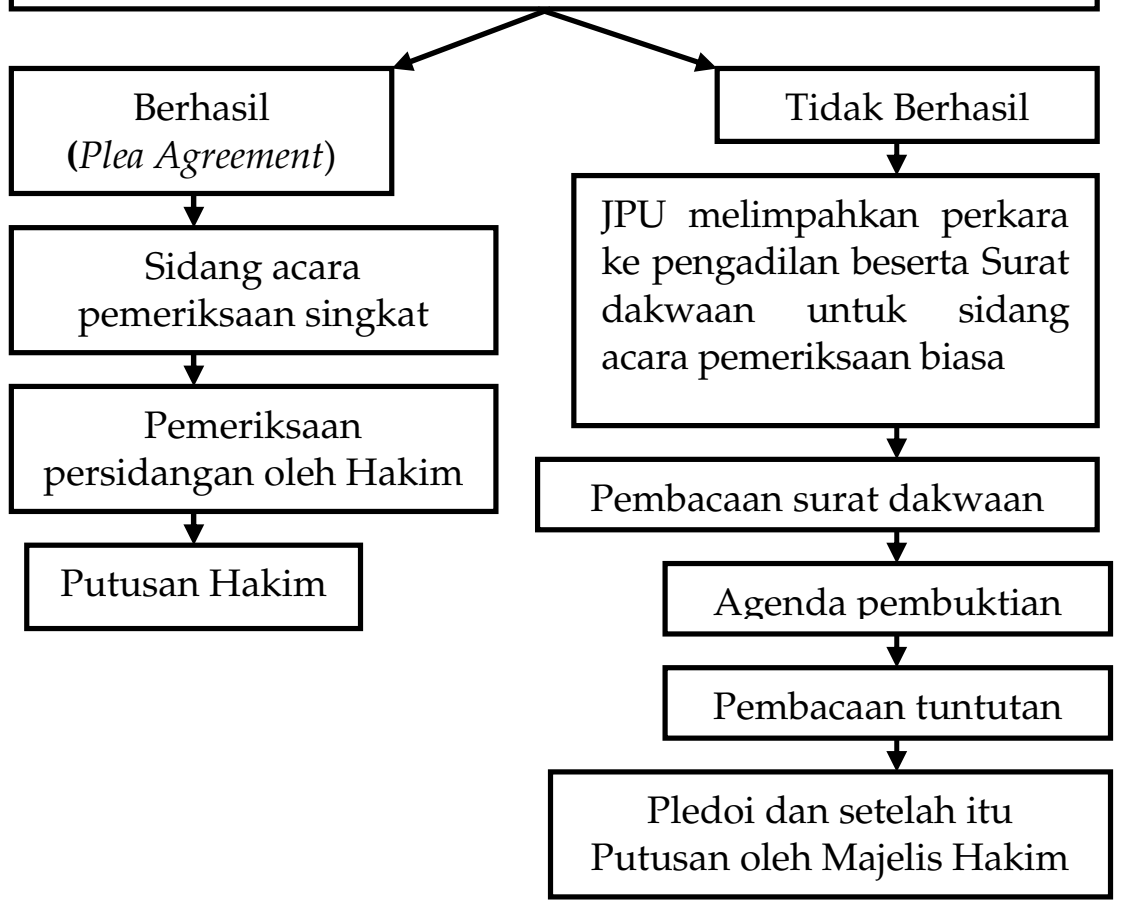




\section{Penutup}

Berdasarkan pembahasan di atas, dapat disimpulkan bahwa, pertama, pengaturan mengenai plea bargainning system di Amerika Serikat diatur dalam Federal Rules of Criminal Procedure, khususnya dalam rule 11. Dalam sistem peradilan pidana di Amerika Serikat, plea bargaining dilakukan pada tahap arraignment dan preliminary hearing. Dengan penerapan plea bargaining system, Amerika Serikat mampu menangani banyaknya perkara yang masuk sehingga sistem peradilan pidana di Amerika Serikat mampu mencegah keluarnya biaya yang tinggi dan waktu yang panjang. Kedua, Plea bargaining merupakan legal problem solving dalam mengatasi penumpukan perkara pidana di Indonesia yang belum mampu terpecahkan hingga hari ini. Urgensi untuk menerapkan plea bargaining dalam proses peradilan pidana di Indonesia dapat dilihat dari berbagai alasan. Alasan filosofis terletak dalam alinea ke-4 Pembukaan UUD NRI 1945 tentang kesejahteraan umum dan keadilan sosial. Alasan yuridis yakni termaktub dalam Pasal 28D ayat (1) UUD NRI 1945 dan Pasal 4 ayat (2) Undang-Undang Nomor 48 Tahun 2009 tentang Kekuasaan Kehakiman. Alasan sosiologis terlihat dari berbagai permasalahan dalam proses pelaksanaan peradilan pidana di Indonesia, yakni seperti lamanya proses penyelesaian perkara, tingginya biaya dalam penyelesaian perkara, serta menumpuknya perkara pidana di pengadilan yang tak kunjung usai. Terakhir, alasan politik hukum, bahwa pembaruan hukum pidana dilakukan sebagai strategi untuk menciptakan hukum yang paling baik yang untuk mengatur, memelihara, dan menjaga konsistensi terwujudnya ide dan cita negara, juga agar hukum pidana yang berlaku sesuai dengan nilai-nilai yang dimiliki masyarakat Indonesia.

Berdasarkan pembahasan di atas, disarankan bahwa, pertama, aturan mengenai plea bargaining system dimasukkan dalam Rancangan Kitab UndangUndang Hukum Acara Pidana. Hal ini mengatur jaminan terhadap hak-hak yang dimiliki oleh terdakwa pada saat melakukan mekanisme plea bargaining serta batasan-batasan waktu terhadap setiap tahapan pemeriksaan agar peradilan pidana yang efektif dan efisien terwujud dan dibentuknya aturan pelaksana yang mengatur mekanisme pelaksanaan plea bargaining system dalam proses peradilan 
pidana di Indonesia. Kedua, perlu adanya pembinaan bagi Jaksa Penuntut Umum dari segi pemahaman teori dan praktik dalam pelaksanaan plea bargaining system, mengingat jaksa merupakan elemen penting dalam pelaksanaan plea bargaining. Hal ini agar proses tersebut dapat terlaksana sebagaimana tujuannya demi tercapainya peradilan pidana yang efektif dan efisien.

\section{Daftar Pustaka}

\section{Buku}

Atmasasmita, Romli, Sistem Peradilan Pidana Kontemporer, Kencana, Jakarta, 2010.

Kusumaadmadja, Mochtar, Konsep-konsep Hukum Dalam Pembangunan, Alumni, Bandung, 2002.

MD., Muh. Mahfud, Politik Hukum, PT. Raja Grafindo Persada, Jakarta, 2009.

Najih, Muhammad, Politik Hukum Pidana: Konsepsi Pembaruan Hukum Pidana dalam Cita Negara Hukum, Setara Press, Malang, 2014.

Tongat, Hukum Pidana Indonesia: Dalam Prespektif Pembaruan, UMM Press, Malang, 2010.

Rahardjo, Satjipto, Negara Hukum yang Membahagiakan Rakyatnya, Genta Publishing, Yogyakarta, 2008.

Reksodiputro, Mardjono, Pembocor Rahasia/Wistle Blowers dan Penyadapan (Wiretapping, Electronic Interception) Dalam Menanggulangi Kejahatan Di Indonesia, Wacana Goverminyboard, Jakarta, 2016.

Shidarta, Mochtar Kusumaatmadja dan Teori Hukum Pembangunan, Epistema Institute, Jakarta, 2012.

Sundari, Perbandingan Hukum dan Fenomena Adopsi Hukum, Cahaya Atma Pustaka, Yogyakarta, 2014.

\section{Jurnal}

Alschuler, Albert, "Plea Bargaining and its History", Journal Articles Unniversity of Chicago Law School, Volume 79, Nomor 1, 1979.

Igor dan Ivana, "Plea Bargaining: A Challenging Issue in the Law and Economics", Faculty Of Law, 2010.

Mulyadi, Lilik, "Menggagas Konsep dan Model Ideal Perlindungan Hukum Terhadap Whistleblower dan Justice Collaborator dalam Upaya Penanggulangan Organized Crime di Indonesia Masa Mendatang", Jurnal Hukum dan Peradilan, Volume III, Nomor 2, 2014.

Langbein, "Understanding the Short History of Plea Bargaining", Yale Law Achool Legal Scholarship Repository, Rev, 261, 1979. 
Nixson dan Syafrudin Kalo, "Perlindungan Hukum terhadap Whistleblower dan Justice Collaborator dalam Upaya Pemberantasan Tindak Pidana Korupsi", USU Law Jurnal, Volume II, Nomor 2, 2013.

Faiz, Mohammad, "Teori Keadilan John Rawls", Jurnal Konstitusi, Volume 6, Nomor 1, 2009.

Muhammad, Rusli, "Pengaturan Whistle Blower dan Justice Collaborator dalam Sistem Peradilan Pidana". Jurnal Hukum Ius Quia Fakultas Hukum Universitas Islam Indonesia, Volume 22, Nomor 2, 2015.

Sidhartha Mohapatra \& Hailshree Saksena, "Plea Bargain : A Uniqie Remedy". New York. http: / / indlaw.com, 2009.

Son Haji dan Gunarto, “Implementasi Kewenangan Diskresi Kepolisian dalam Penanganan Tindak Pidana di Polres Demak Jawa Tengah", Jurnal Hukum Khaira Ummah, Volume 13, Nomor 1, 2018.

Welsh S. White, "A Proposal for Reform of the Plea Bargaining Process", University of Pennyslvania Law Revie, Vol. 119: 439, 1971.

\section{Peraturan Perundang-undangan}

The Federal of Criminal Procedure

Undang-Undang Dasar Negara Republik Indonesia Tahun 1945

Undang-Undang Nomor 31 Tahun 2014 tentang Perubahan atas Undang-Undang

Nomor 13 Tahun 2006 tentang Lembaga Perlindungan Saksi dan Korban

Undang-Undang No. 48 Tahun 2009 tentang Kekuasaan Kehakiman

Undang-Undang No. 16 Tahun 2004 tentang Kejaksaan Republik Indonesia

Undang-Undang No. 2 Tahun 2002 tentang Kepolisian Negara Republik Indonesia.

Undang-Undang No. 8 Tahun 1981 tentang Hukum Acara Pidana

\section{Internet}

Chakim, Luthfi, 2015. Plea Bargaining. http:/ / www.lutfichakim.com.

Mahkamah Agung Republik Indonesia, 2015. http:// kepaniteraan. mahkamahagung.go.id.

Misha, 2005. Issues of Overcrowded Prisons and the Trade-Off "Plea Bargaining in the Criminal Justice". http:/ / www .associatedcontent.com.

Wildya. Sistem Peradilan Pidana di Amerika Serikat. https: / /www.slideshare.net. 